\title{
Lysosomal Lipid Storage Diseases
}

\author{
Heike Schulze and Konrad Sandhoff \\ LIMES (Life and Medical Sciences Institute), Membrane Biology and Lipid Biochemistry Unit, c/o Kekulé- \\ Institut für Organische Chemie und Biochemie, University of Bonn, D-53121 Bonn, Germany \\ Correspondence: sandhoff@uni-bonn.de
}

Lysosomal lipid storage diseases, or lipidoses, are inherited metabolic disorders in which typically lipids accumulate in cells and tissues. Complex lipids, such as glycosphingolipids, are constitutively degraded within the endolysosomal system by soluble hydrolytic enzymes with the help of lipid binding proteins in a sequential manner. Because of a functionally impaired hydrolase or auxiliary protein, their lipid substrates cannot be degraded, accumulate in the lysosome, and slowly spread to other intracellular membranes. In Niemann-Pick type $\mathrm{C}$ disease, cholesterol transport is impaired and unesterified cholesterol accumulates in the late endosome. In most lysosomal lipid storage diseases, the accumulation of one or few lipids leads to the coprecipitation of other hydrophobic substances in the endolysosomal system, such as lipids and proteins, causing a "traffic jam." This can impair lysosomal function, such as delivery of nutrients through the endolysosomal system, leading to a state of cellular starvation. Therapeutic approaches are currently restricted to mild forms of diseases with significant residual catabolic activities and without brain involvement.

ysosomal lipid storage diseases are a group of Linherited catabolic disorders in which typically large amounts of complex lipids accumulate in cells and tissues. Macromolecules such as complex lipids and oligosaccharides are constitutively degraded in the acidic compartments of the cell, the endosomes, and lysosomes, into their building blocks. The resulting catabolites are exported to the cytosol and reused in cellular metabolism. When lysosomal function is impaired because of a defect in a catabolic step, degradation cannot proceed normally and undegraded compounds accumulate. Lysosomal lipid storage diseases comprise mainly the sphingolipidoses, Niemann-Pick type C disease (NPC), and Wolman disease, including the less severe form of this disease, called cholesteryl ester storage. NPC is a complex lipid storage disease mainly characterized by the accumulation of unesterified cholesterol in the late endosomal/lysosomal compartment (Bi and Liao 2010). The sphingolipidoses are caused by defects in genes encoding proteins involved in the lysosomal degradation of sphingolipids (Kolter and Sandhoff 2006). First reports on these diseases were given more than a century ago. Already in 1881, Warren Tay described the clinical symptoms of a disease, which is today called Tay-Sachs disease (Tay 1881). After Christian de Duve discovered the lysosome in 1955 (de Duve 2005), Henri-Géry Hers established the first correlation between an enzyme

Editor: Kai Simons

Additional Perspectives on The Biology of Lipids available at www.cshperspectives.org

Copyright (C) 2011 Cold Spring Harbor Laboratory Press; all rights reserved; doi: 10.1101/cshperspect.a004804

Cite this article as Cold Spring Harb Perspect Biol 2011;3:a004804 
deficiency and a lysosomal storage disorder (Pompe's disease) in 1963 (Hers 1963). In the following decades, the enzymes and cofactors deficient in the sphingolipidoses have been identified. Though lysosomal lipid storage diseases have been known for a long time, treatment is only available for a few mild forms of the diseases, such as the adult forms of Gaucher disease (Barton et al. 1991). For several lysosomal storage diseases, therapies like enzyme replacement or bone marrow transplantation are in the clinical trial stage (Platt and Lachmann 2009). For a long time, lysosomal diseases have been considered a problem of superabundance (storage) in which the storage material can slowly spread to other cellular membranes, impairing their function. More recently, it came into focus that massive storage prevents lysosomal functions such as nutrition delivery through the endolysosomal system, leading to a state of cellular starvation. In mouse models of both GM1 and GM2 gangliosidoses iron is progressively depleted in brain tissue. Administration of iron prolonged survival in the diseased mice by up to $38 \%$ (Jeyakumar et al. 2009).

\section{LYSOSOMES AS STOMACHS OF THE CELL PROVIDE CELLS WITH NUTRIENTS}

Lysosomes provide cells with nutritients, and should be thought of as stomachs of the cell (Kolter and Sandhoff 2010). Export of metabolites from the lysosome is mediated by transport proteins within the lysosomal perimeter membrane (Sagné and Gasnier 2008). Defective transport across the lysosomal membrane can lead to intralysosomal storage and starvation of the cell, as in Salla disease, where sialic acid is accumulated (Ruivo et al. 2009). Cobalamin uptake takes place via endocytosis and release from the lysosomes. Defects in the presumed lysosomal membrane exporter for cobalamin, LMBD1, lead to the accumulation of the vitamin in the lysosomes, reducing its conversion to enzyme cofactors (Rutsch et al. 2009). Furthermore, lysosomes play an important role in iron metabolism (Kurz et al. 2008), supplying the cytosol with $\mathrm{Fe}^{2+}$ either by autophagy or by release from endocytosed transferrin. Many autophagocytosed proteins such as ferritin, and proteins from the electron transport chain, contain iron. Nondividing cells, (i.e., neurons), might fulfill their need in iron ions largely by reuse of catabolites of autophagocytosed ironcontaining proteins.

Mutations in the human TRPML1 gene, coding for a predicted late endosomal and lysosomal iron channel protein, cause mucolipidosis type IV disease. Impaired iron transport may contribute to hematological and degenerative symptoms of mucolipidosis type IV patients (Dong et al. 2008).

Besides the degradation of defective proteins, the supply with nutrients such as iron ions even under nonstarving conditions is an essential function of autophagy. Mice lacking Atg7, a gene essential for autophagy, show massive neurodegeneration (Komatsu et al. 2006). Uptake of exogenous iron by dividing cells is mediated through endocytosed transferrin (and the transferrin receptor). The iron is released in the endosomes at decreased $\mathrm{pH}$-values and can leave the compartment to the cytosol by the divalent metal transporter- 1 and may reach the outer mitochondrial membrane by temporary close contact of the organelles (Zhang et al. 2005). However, $\mathrm{Fe}^{2+}$ ions should always be protein bound because free $\mathrm{Fe}^{2+}$ ions can promote the formation of very reactive hydroxylradicals via the Fenton reaction $\left(1 . \mathrm{Fe}^{2+}+\mathrm{O}_{2}\right.$ $\rightarrow \mathrm{Fe}^{3+}+\mathrm{O}_{2}^{\bullet-} ; 2$. $2 \mathrm{H}^{+}+2 \mathrm{O}_{2}^{--} \rightarrow \mathrm{H}_{2} \mathrm{O}_{2}+$ $\left.\mathrm{O}_{2} ; 3 \cdot \mathrm{Fe}^{2+}+\mathrm{H}_{2} \mathrm{O}_{2} \rightarrow \mathrm{Fe}^{3+}+\mathrm{OH}^{-}+\mathrm{OH}^{\bullet}\right)$.

\section{SPHINGOLIPIDS}

Sphingolipids and glycosphingolipids are ubiquitous components of mammalian cell membranes. They are characterized by the presence of a hydrophobic membrane anchor, ceramide, and a sphingoid base linked via the amino group to a fatty acid. Its terminal hydroxyl group is bound to a hydrophilic headgroup, phosphorylcholine in the case of sphingomyelin or a carbohydrate headgroup in the case of glycosphingolipids (GSL) (Fig. 1). Biosynthesis of glycosphingolipids starts with the formation of ceramide at the cytoplasmic face of the 

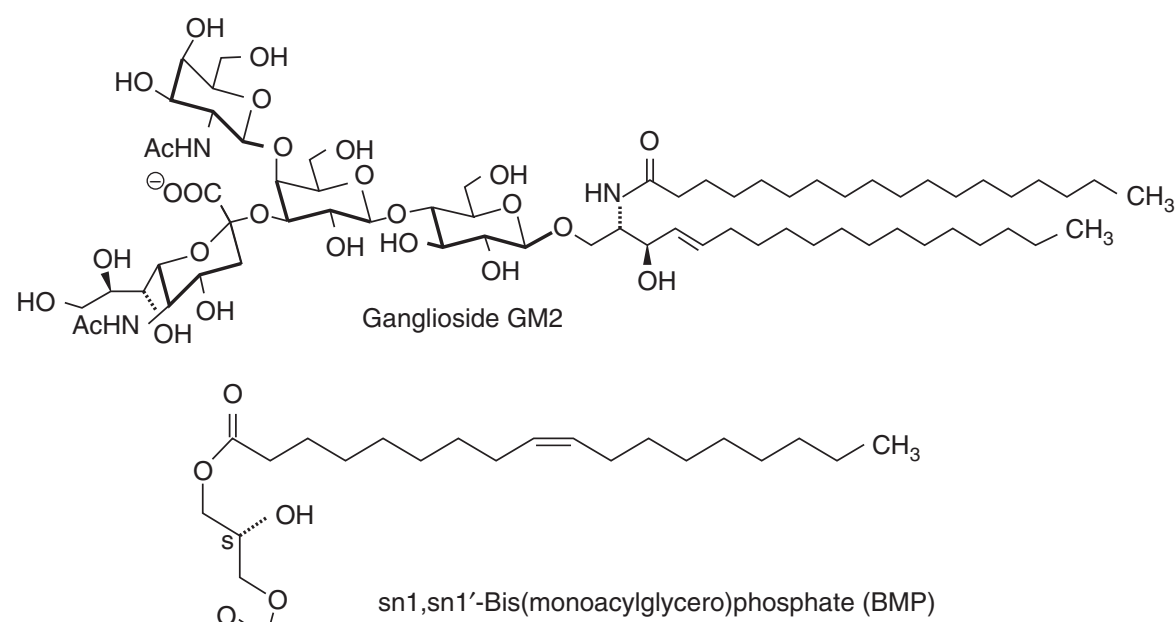<smiles>C[Si]([O])(O)OP(=O)([O-])[O-]</smiles>
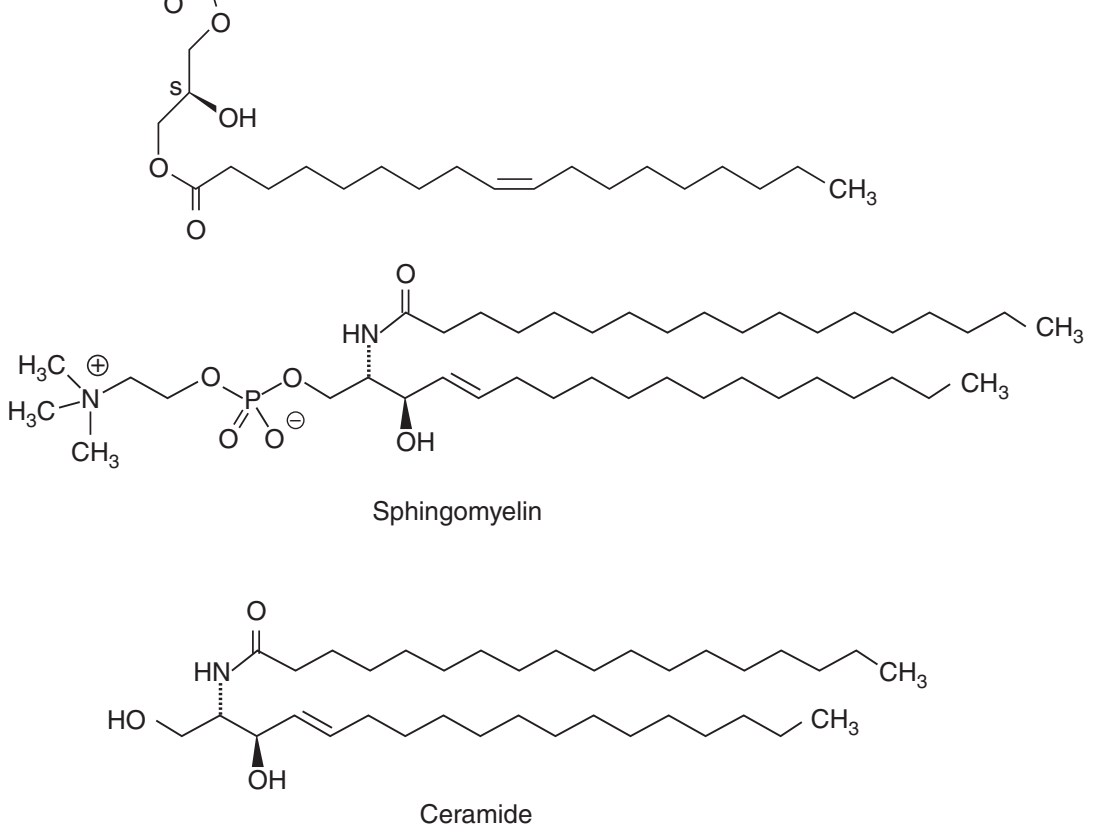

Figure 1. Structures of ganglioside GM2, sphingomyelin, ceramide, and BMP.

endoplasmatic reticulum (ER) membrane (Merrill 2002; Kolter and Sandhoff 1999). De novo biosynthesis competes with sphingolipid formation by salvage pathways using building blocks (e.g., sphingoid bases) released from the lysosomal compartments. Depending on the cell type, 50\%-90\% of glycosphingolipids are derived from the salvage pathways (Gillard et al. 1998; Tettamanti et al. 2003). During biosynthesis, ceramides are transferred to the cytosolic leaflet of the Golgi membrane by secretory vesicular flow and by the lipid transfer protein CERT (Hanada et al. 2003), where glucosylceramide is formed and translocated to the luminal face. Subsequent glycosylation reactions give rise to the complex carbohydrate pattern of gangliosides. After their biosynthesis, complex glycosphingolipids reach the outer 
surface of plasma membranes by vesicular exocytotic membrane flow. Sphingomyelin is formed from ceramide and phosphatidylcholine at the luminal side of the trans-Golgi network and at the plasma membrane (Tafesse et al. 2007).

To date, only very few diseases associated with impaired sphingolipid biosynthesis are known. Partial deficiency of the biosynthetic enzyme lactosylceramide $\alpha 2,3$ sialyltransferase (GM3 synthase) causes an autosomal recessive infantile-onset symptomatic epilepsy syndrome (Simpson et al. 2004). Mutations in the SPTLC1 gene coding for a subunit of the serine palmitoyltransferase, lead to enhanced neuronal apoptosis because of elevated levels of deoxyceramides (Dawinks et al. 2001; Bejaoui et al. 2002). They cause an adult-onset, hereditary sensory, and autonomic neuropathy type I (HSAN1). The mutations alter amino acid selectivity of the serine palmitoyltransferase enzyme, leading to condensation of palmitate with alanine and glycine, in addition to serine, and resulting in the accumulation of two atypical neurotoxic deoxysphingoid bases (Penno et al. 2010).

\section{SPHINGOLIPIDOSES}

The sphingolipidoses are inherited lipid storage diseases caused by defects in genes encoding proteins of the lysosomal catabolism. All sphingolipidoses are inherited in an autosomal recessive mode, with the exception of Fabry disease, which follows an X-linked recessive mode of inheritance (Desnick et al. 2001). GSLs are degraded along a strictly sequential pathway in humans (Fig. 2). For almost every degradation step, a disease has been described in which the correlated enzyme or activator protein is defective. Lactosylceramide can be degraded by two enzyme/activator systems (Zschoche et al. 1994). Therefore, no single enzyme defect is known that leads to isolated lactosylceramide storage. However, lactosylceramide accumulates, together with other sphingolipids, when several cofactors are absent simultaneously, as it is the case in prosaposin deficiency (Bradova et al. 1993).

\section{LIPID SORTING AND FORMATION OF INTRAENDOLYSOSOMAL VESICLES}

Water-soluble macromolecules such as proteins and oligosaccharides can easily be reached by soluble enzymes and be degraded in the endolysosomal system. However, degrading membrane-lipids in an organelle without destroying the integrity of its perimeter membrane requires more complex sorting and disintegration systems. This led to the assumption that two distinct pools of membranes exist in the late endolysosomal compartment, which differ in lipid and protein composition (Fürst and Sandhoff 1992; Kolter and Sandhoff 2010). Lipids reach the lysosomal compartment either as part of the limiting membrane, or as part of intraendosomal membranes, the main site of sphingolipid degradation. The lysosomal perimeter membrane is protected from degradation by a glycocalyx facing the lumen of the organelle and composed of glycoproteins heavily glycosylated with lactosamine units (Eskelinen et al. 2003). Intralysosomal membranes have initially been observed in cells of patients with sphingolipid storage diseases such as GM1 gangliosidosis (Suzuki and Chen 1968) or combined sphingolipid activator protein deficiency (Harzer et al. 1989), where nondegradable lipids accumulate in multivesicular storage bodies. Multivesicular bodies are formed by inward budding of the limiting endosomal membrane, mediated by the sequential action of three endosomal sorting complexes required for transport, ESCRT-I, -II, -III (Saksena et al. 2007; Wollert and Hurley 2010). During endocytosis and maturation of endosomes, the luminal $\mathrm{pH}$ value decreases, and lipid composition of the internal membranes is adjusted for degradation (Fig. 3). Membrane-stabilizing cholesterol is sorted out and a main activator of enzymatic sphingolipid degradation, bis-(monoacylglycero)-phosphate (BMP), is formed (Möbius et al. 2003). BMP is a characteristic anionic lipid on the surface of intralysosomal membranes, which is negatively charged even at lysosomal $\mathrm{pH}$ values. The perimeter membrane does not contain BMP (Möbius et al. 2003). Because of its unusual sn1, sn1'-configuration, BMP is only slowly 


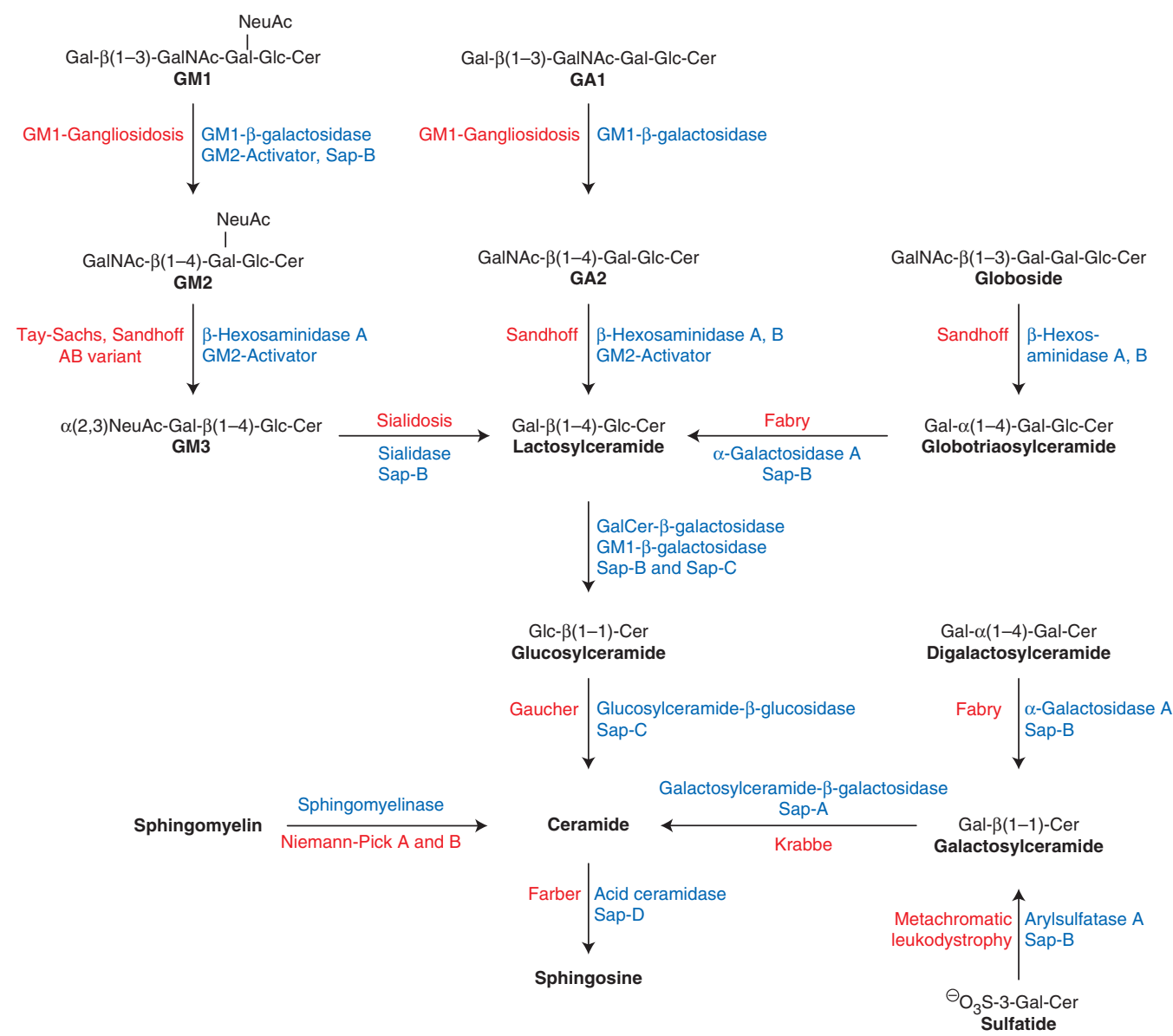

Figure 2. Degradation of selected sphingolipids in the lysosomes of the cells. The eponyms of individual inherited diseases are given. Activator proteins required for the respective degradation step in vivo are indicated. Variant $\mathrm{AB}, \mathrm{AB}$ variant of GM2 gangliosidosis (deficiency of GM2-activator protein); Sap, saposin (adapted from Kolter and Sandhoff [2005] and reprinted here with permission from Annual Review of Cell and Developmental Biology (C) 2005).

degraded by lysosomal phospholipases (Matsuzawa and Hostetler 1979). BMP derives from phosphatidylglycerol generated in the ER and from cardiolipin, which reaches the lysosomes presumably as part of mitochondria by macroautophagy (Brotherus and Renkonen 1977; Amidon et al. 1996). Together with smaller amounts of phosphatidylinositol (Kobayashi et al. 1998) and dolichol phosphate (Chojnacki and Dallner 1988), BMP causes a negative charge of intralysosomal membranes. Because of their isoelectric points, most activator proteins and hydrolytic enzymes, such as acid sphingomyelinase, are positively charged at the acidic $\mathrm{pH}$ values of the lysosomes. As polycations, they should adhere to the surfaces of intralysosmal vesicles. Binding of the cationic lysosomal proteins to the negatively charged surface of the inner vesicles allows degradation of lipids at the membrane-water interphase. Some cationic amphiphilic drugs, such as the antidepressant desipramine, can interfere with the negatively charged surface, leading to release and subsequent proteolysis of the hydrolytic enzyme. In the case of acid sphingomyelinase, this leads to a drug induced lipidosis (Kölzer et al. 2004). Based on in vitro experiments we assume that acid sphingomyelinase is already quite active in 


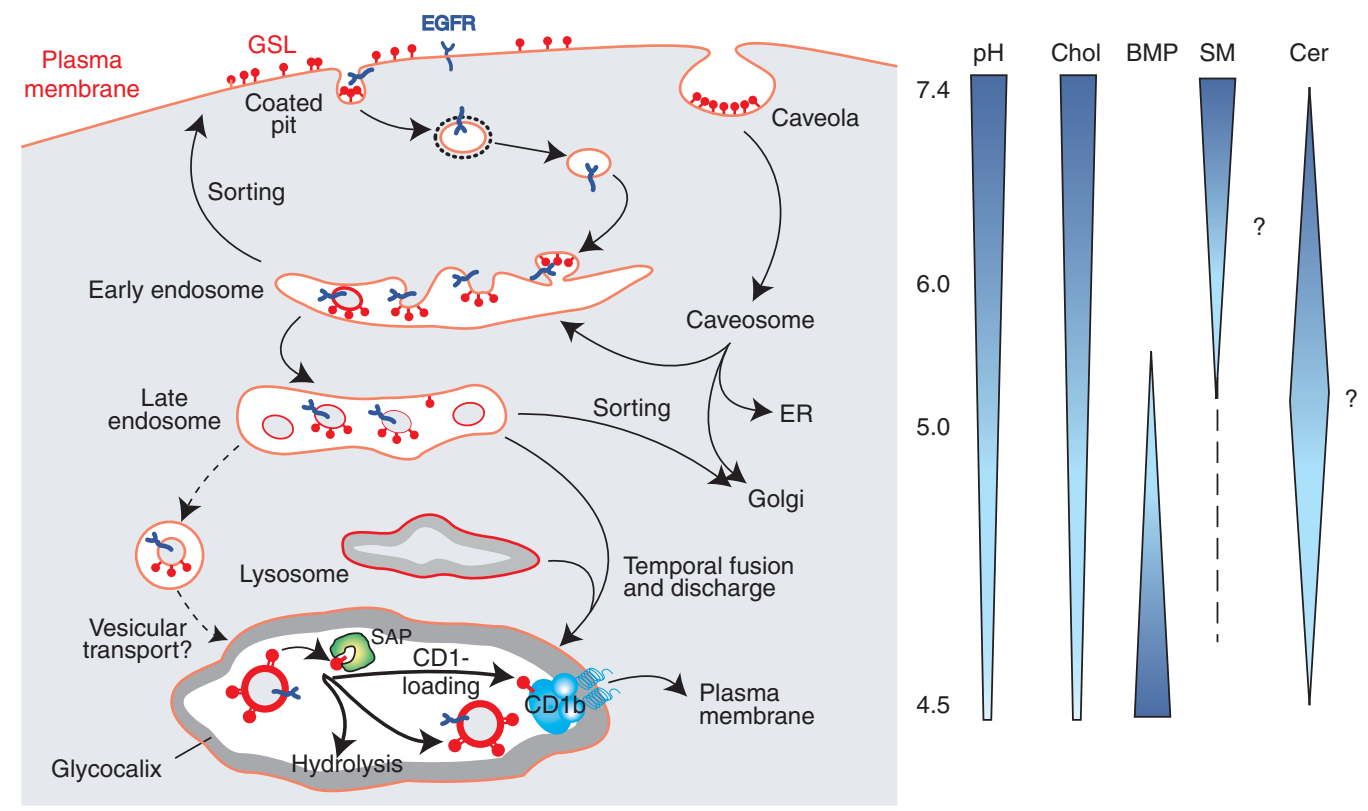

Figure 3. Model of endocytosis and lysosomal digestion of membranes. Glycosphingolipids (GSL) are highlighted on the plasma membrane (PM) and on internal membranes, and gradients of $\mathrm{pH}$ in the lumen of the organelles and lipids in the intraendolysosomal vesicles; cholesterol (Chol), BMP, sphingomyelin (SM; hypothetical), and ceramide (Cer; hypothetical) are shown (adapted from Kolter and Sandhoff [2005] and reprinted here with permission from Annual Review of Cell and Developmental Biology (C)2005). EGFR epidermal growth factor receptor, SAP sphingolipid activator proteins.

late endosomes and converts sphingomyelins of the intraendosomal vesicles and lipid aggregates into ceramides (Abdul-Hammed et al. 2010). This would stimulate the cholesterol transfer mediated by the NPC-2 protein. This transfer is stimulated by BMP and ceramide in the vesicular membranes and inhibited by sphingomyelin (Abdul-Hammed et al. 2010).

\section{LYSOSOMAL LIPID BINDING PROTEINS}

In addition to hydrolyzing enzymes and anionic lipids, especially BMP, lysosomal degradation of glycosphingolipids requires auxiliary proteins, the lysosomal lipid binding proteins (LLBP). Other membrane compounds such as phospholipids can apparently be degraded without their help. GSLs with short carbohydrate chains of four or less sugars bound to intralysosomal membranes are not sufficiently accessible to the water-soluble enzymes present in the lysosomal lumen. LLBP bind, solubilize, and present membrane-lipids to their respective hydrolases for degradation (Fürst and Sandhoff 1992). They encompass five sphingolipid activator proteins, the saposins A-D (Sap-A-D), and the GM2 activator protein (Conzelmann and Sandhoff 1979; Sandhoff et al. 2001). SapA-D derives from one common precursor protein, the prosaposin ( $\mathrm{p}$-Sap).

\section{MOLECULAR AND CELLULAR PATHOGENESIS OF SPHINGOLIPID STORAGE DISEASES}

\section{Organ and Cell Specificity of Sphingolipid Storage}

Sphingolipid storage diseases are caused by defective catabolic activities in the endolysosomal system of the cells. Lysosomal accumulation occurs predominantly in cells and organs that have the highest rates of biosynthesis or uptake 
of the undegradeable sphingolipids and their precursors. For example, blocks in ganglioside catabolism result predominantly in neuronal degeneration, whereas blocks in sulfatide and galactosylceramide (GalCer) degradation lead to myelin diseases. Blocks in glucosylceramide (GlcCer) catabolism primary lead to GlcCer and glucosylsphingosine storage in macrophages (in blood, spleen, and in Kupffer cells of the liver), thus generating Gaucher cells, because they have the highest load of GSLs to degrade, their own synthesized GSLs and all the GSL material they ingest, (e.g., from red blood cells) (Kolter and Sandhoff 2010).

\section{Threshold Theory}

Genetic mutations may well result in a complete functional loss of the encoded lysosomal hydrolase or LLBP, leading to severe clinical forms, usually infantile (Tay-Sachs disease, NiemannPick disease type A) or even prenatal fatal disease ("Collodian Babies," p-Sap deficiency), whereas the generation of variant lysosomal proteins may well cause protracted forms of the disease (juvenile, adult, chronic forms). The level of residual catabolic activity is one out of several factors contributing to the molecular pathogenesis and clinical form of the disease. In the threshold theory, a correlation between functional residual catabolic activity and the progression of the lipid storage disease has been formulated (Conzelmann and Sandhoff 1983-1984), which was basically confirmed for different clinical forms of diseases such as metachromatic leukodystrophy (Leinekugel et al. 1992; Tan et al. 2010), GM2-gangliosidosis (Leinekugel et al. 1992), Gaucher (Gieselmann 2005), and Niemann-Pick type A and B diseases (Ferlinz et al. 1995).

\section{FORMATION OF TOXIC COMPOUNDS AND CELLULAR PATHOGENESIS (LYSOSPHINGOLIPIDS AS CATIONIC AMPHIPHILES)}

Cationic lysocompounds (galactosylsphingosine (GalSo), glucosylsphingosine (GlcSo), sphingosine (So), sphinganine (Sa), but also lysoGM2 and lysosulfatides) are toxic. They are micelleforming inhibitors of catabolic enzymes, and presumably also compensate negative charge of inner membranes in lysosomes.

GalSo is specifically formed in oligodendrocytes. Its accumulation kills these myelinforming cells in Krabbe disease, leading to an impaired myelination (Suzuki 2003).

GlcSo is toxic. It inhibits glucosylceramide$\beta$-glucosidase (Sarmientos et al. 1986) and accumulates in severe forms of Gaucher disease. "Collodian babies" with no residual glucosylceramide- $\beta$-glucosidase activity have a severe skin phenotype with no functional water barrier because of a block of ceramide formation in the extracellular space of the epidermis. These babies loose dramatic amounts of water through the skin and die within two hours after birth.

A moderate accumulation of sphingosine and sphinganine also contributes to the molecular pathology of Niemann-Pick type C disease (Rodrigez-Lafrasse et al. 1994; Lloyd-Evans and Platt 2010).

Complex lysoglycolipids (lysosulfatide, lyso GM2, etc.) are minor storage compounds and their contribution to the pathogenesis of their respective disease is presumed to be small (Neuenhofer et al. 1986; Rosengren et al. 1989).

\section{ACCUMULATION OF SPHINGOLIPIDS IN CELLULAR MEMBRANES OUTSIDE THE ENDOLYSOSOMAL SYSTEM}

Storage of GlcCer (in Gaucher disease) (Jmoudiak and Futermann 2005), Globotriaosylceramide (Gbose3) (in Fabry disease), GM2, and GM1 (Tessitore et al. 2004) has also been identified in other cellular membranes besides the endolysosomal system. During months and years of disease progress, storage compounds spill over from endolysosomal membranes to other cellular membranes by membrane-flow, membrane contact, or propably also by protein transport.

Accumulation of these storage compounds in ER membranes affects several functions of the organelle, (e.g., $\mathrm{Ca}^{2+}$ homeostasis) (LaPlante et al. 2002; Pelled et al. 2003) and signaling cascades (Takamura et al. 2008). 


\section{LABILIZATION OF LYSOSOMAL PERIMETER MEMBRANES}

The integrity of the limiting lysosomal membrane is essential for cell survival. It has been shown that Hsp70 can bind to BMP and stabilize lysosomes and ASM activity (Kirkegaard et al. 2010). Cationic amphiphilic drugs (CADs) are lysosomotropic agents. They increase the permeability of lysosomal perimeter membranes, and cause a "traffic jam" by secondary accumulation of further lipid compounds. As neutral amphiphiles, they penetrate membranes, and accumulate as protonated, membrane impermeable compounds in the acidic lysosomal compartment. This traffic jam attenuates autophagy and could also impair uptake of nutritients and removal of damaged organelles and proteins, as has been observed in GM1 gangliosidosis, Niemann-Pick disease type C, and Sandhoff disease. Sphingosine storage in Niemann-Pick type $C$ disease reduces lysosomal $\mathrm{Ca}^{2+}$ ion content and impairs membrane trafficking (Lloyd-Evans and Platt 2010).

Defective processing of transferrin bound $\mathrm{Fe}^{2+}$ could also cause oxidative stress in lysosomes. Generation of free, not protein bound $\mathrm{Fe}^{2+}$ ions could trigger the formation of radical oxygen species (ROS) by the Fenton reaction and may give rise to the formation of lipofuscin or "age pigment." Accumulation of lipofuscin seems to hinder normal autophagy and may be an important factor behind aging and age-related pathologies (Kurz et al. 2008). Enhanced oxidative stress causes lysosomal membrane permeabilization (Kurz et al. 2008).

NPC1 knockout mice show increased levels of many potentially atherogenic cholesterol auto-oxidation products (e.g., with hydroxyl groups in positions 5,6 , or 7 ) (Tint et al. 1998). However, levels of enzymatically formed 27-hydroxycholesterol are decreased (Zhang et al. 2008).

\section{GM1 GANGLIOSIDOSIS (AND MORQUIO TYPE B DISEASE)}

GM1-gangliosidosis is caused by an inherited deficiency of the lysosomal enzyme GM1- $\beta$-galactosidase (Suzuki et al. 2001; Sano et al. 2005).
In the presence of either the GM2-activator protein or Sap-B, GM1- $\beta$-galactosidase catalyzes the cleavage of terminal $\beta$-D-galactose from ganglioside GM1 resulting in GM2. The reaction is stimulated by anionic phospholipids such as BMP (Wilkening et al. 2000).

Similarly, to other sphingolipidoses, three clinical forms of GM1-gangliosidosis can be distinguished: In infantile (type 1) GM1-gangliosidosis, developmental arrest and progressive deterioration of the nervous system occur in early infancy. The late infantile/juvenile form (type 2) is characterized by progressive neurologic symptoms in children, and the adult/chronic form (type 3) occurs in young adults. Besides spontaneous animal models of the disease (Suzuki et al. 2001), an engineered mouse model resembling the neurological phenotype of human GM1 gangliosidosis has been analyzed (Hahn et al. 1997).

Because of its changed substrate specificity, defective GM1- $\beta$-galactosidase can also lead to Morquio type $\mathrm{B}$ disease. Morquio type $\mathrm{B}$ disease clinically resembles a mild phenotype of Morquio A disease, where keratan sulfate accumulates because of N-acetylgalactosamine-6sulfatase deficiency.

\section{GM2 GANGLIOSIDOSES}

The GM2 gangliosidoses are a group of three sphingolipidoses that result from defects in degradation of ganglioside GM2 and related glycolipids (Sandhoff 1969; Sandhoff et al. 1971; Gravel et al. 2001). In vivo, the degradation of GM2 requires the presence of the GM2- activator protein. Three lysosomal $\beta$-hexosaminidases, which differ in the combination of their two subunits $(\alpha$ and $\beta)$ and their substrate specificity have been described. $\beta-$ Hexosaminidase $\mathrm{A}$ (consisting of the $\alpha$ and $\beta$ subunits) cleaves terminal $\beta$-glycosidically linked $\mathrm{N}$ acetylglucosamine- and $\mathrm{N}$-acetylgalactosamine residues from negatively charged and uncharged glycoconjugates. $\beta$-Hexosaminidase $B$ $(\beta \beta)$ cleaves uncharged substrates such as glycolipid GA2 and oligosaccharides with terminal $\mathrm{N}$-acetylhexosamine residues. $\beta$-Hexosaminidase $S(\alpha \alpha)$ contributes to the degradation of 
glycosaminoglycans and sulfated glycolipids. The inborn deficiency of the GM2-activator as well as the deficiency of the $\alpha$ - or $\beta$-chain of the $\beta$-hexosaminidase isoenzymes leads to one of the three different variants of this disease that are named according to the isoenzyme remaining intact. Mouse models for Tay-Sachs and Sandhoff disease surprisingly differ severely in their phenotypes. The Sandhoff mouse, lacking hexosaminidases $\mathrm{A}$ and $\mathrm{B}$, shows a severe neurological phenotype, corresponding to the human infantile onset variant. However, the Tay-Sachs mouse model, lacking hexosaminidases $A$ and $S$, showed no significant neurological phenotype. The reason for the difference is the specificity of the sialidase, which is different in mouse and human (Sango et al. 1995). Mouse sialidase, in contrast to the human enzyme, accepts GM2 as a substrate and converts it slowly to GA2, which is further degraded by the still intact $\beta$-hexosaminidase $\mathrm{B}$ in the Tay-Sachs mice.

\section{Tay-Sachs Disease (B-Variant)}

The B-variant of the GM2 gangliosidoses is because of an $\alpha$-chain deficiency, and the subsequent deficiency of hexosaminidases A and S, but with normal hexosaminidase B. In B1 variant, the patient hexosaminidase A lost its catabolic activity against ganglioside GM2 but not against neutral substrates (Kytzia and Sandhoff 1985; Tanaka et al. 1990). Clinically, the B-variant of GM2 gangliosidoses can be subclassified into infantile, juvenile, chronic, and adult forms, corresponding to increasing residual enzyme activity (Leinekugel et al. 1992).

The infantile form, known as Tay-Sachs disease (Filho and Shapiro 2004), has a higher prevalence among Ashkenazi Jews with a heterozygote frequency of 1:27.

\section{Sandhoff Disease}

The 0-variant of GM2-gangliosidosis was the first gangliosidosis for which the underlying enzymatic defect, a functional loss of both hexosaminidases A and B, was identified. It is characterized by storage of negatively charged glycolipids characteristic for Tay-Sachs disease, but also by elevated levels of uncharged glycolipids such as glycolipid GA2 in the brain and globoside in visceral organs (Sandhoff 1969; Sandhoff et al. 1971).

\section{AB-Variant of GM2-Gangliosidosis}

The $\mathrm{AB}$-variant is characterized by normal $\beta$-hexosaminidase $A, B$, and $S$ activities, but a deficient lipid binding protein, the GM2-activator protein. The clinical picture resembles that of Tay-Sachs disease.

\section{FABRY DISEASE}

Fabry disease is an X-chromosomal-linked lysosomal storage disorder with a recessive mode of inheritance. The disease is caused by a deficient $\alpha$-galactosidase A enzyme that results in intracellular accumulation of neutral glycosphingolipids (predominantly Gbose3). The disease manifests itself primarily in affected hemizygous males and to some extent in heterozygous females ("carrier") and is characterized by progressive clinical manifestations and premature death from renal failure, stroke, and cardiac disease (Linhart and Elliott 2007; Zarate and Hopkin 2008). Gbose3 accumulates in cardiomyocytes, conduction system cells, valvular fibroblasts, endothelial cells, and vascular smooth muscle cells.

\section{GAUCHER DISEASE}

Gaucher disease is the most common form of the sphingolipidoses (Beutler et al. 2001). It is caused by the deficiency of glucosylceramide$\beta$-glucosidase (also called glucocerebrosidase) leading to accumulation of glucosylceramide. Three different types of Gaucher disease are distinguished: The attenuated form, Gaucher disease type I, has a nonneuropathic course and is the most frequent form of this disease. It has a frequency of 1: 50,000-200,000 births, but is higher amongst the Ashkenazi Jewish population (1:1000). The life expectancy of these patients ranges between 6 and 80 years. Brady developed an enzyme replacement therapy for this type of Gaucher disease (Barton 
et al. 1990; Brady 2006). Gaucher disease type II, the acute form, is a very rare panethnic disease characterized by an additional storage of the toxic glucosylsphingosine and the involvement of the nervous system with early onset and a life expectancy of less than two years. The subacute or juvenile form, Gaucher disease type III, is an intermediate variant of the other two types. In all variants, patients may show hepatosplenomegaly, anemia, thrombocytopenia, and bone damage. The severity of these symptoms differs widely, but is inversely correlated to the residual enzyme activity determined in skin fibroblasts of Gaucher patients (MeivarLevy et al. 1994). Complete glucosylceramide$\beta$-glucosidase deficiency leads to a perinatal fatal form, the "collodion baby" phenotype with a severe impairment of skin function (Liu et al. 1988).

\section{NIEMANN-PICK DISEASE TYPES A AND B}

Accumulation of sphingomyelin in NiemannPick disease type A and B (NPD A and B) is caused by mutations in the sphingomyelin phosphodiesterase 1 gene (SMPD1) encoding for acid sphingomyelinase (ASM) (Ferlinz et al. 1991). Niemann-Pick disease type C shows a similar clinical appearance and sphingomyelin accumulation, but is caused by impaired cholesterol transport. The modular structure of acid sphingomyelinase includes a Sap-like domain and a catalytic domain (Schuchman and Desnick 2001; Lansmann et al. 2003). Type A NPD is a fatal disorder of infancy caused by an almost complete ASM deficiency and results in a life expectancy of 2 to 3 years. Type B NPD is a phenotypically variable disorder with residual ASM activities of up to $4 \%$ of normal and with little or no involvement of the nervous system.

\section{KRABBE DISEASE}

Krabbe disease or globoid cell leukodystrophy is caused by an inherited deficiency of galactosylceramide- $\beta$-galactosidase (Suzuki and Suzuki 1970; Pastores 2009). This membrane-associated enzyme hydrolyzes galactosylceramide, which occurs predominantly in oligodendrocytes and kidney cells, to ceramide and galactose. This enzyme is stimulated in vivo by Sap-A and Sap-C it also cleaves the toxic galactosylsphingosine to galactose and sphingosine. Although there is some storage, especially in oligodendrocytes of the (globoid cells), the enzyme deficiency does not lead to substantial substrate accumulation, because of the rapid loss of oligodendrocytes producing and accumulating the toxic galactosylsphingosine (Suzuki 2003).

\section{METACHROMATIC LEUKODYSTROPHY}

Metachromatic leukodystrophy (MLD) is a lysosomal storage disease caused by the deficiency of arylsulphatase A (ASA) (Mehl and Jatzkewitz 1965; Gieselmann 2008) resulting in the accumulation of sulfatides in several tissues. Arylsulfatase A is essential for the conversion of sulfatides into galactosylceramides and sulfate in the presence of Sap-B (Mehl and Jatzkewitz 1964). Sulfated glycolipids occur mainly in the myelin sheaths in the white matter of the brain, in the peripheral nervous system, and in the kidney tissue. MLD can be classified into a late infantile, a juvenile, and an adult form, correlating with increasing residual catabolic activities (Leinekugel et al. 1992). The clinical and histopathologic manifestations of MLD are fundamentally caused by a demyelination process. This phenomenon appears to be secondary to sulfatide-induced changes in oligodendrocytes and Schwann cells. Deficiency of Sap-B, the cofactor required for sulfatide cleavage by ASA in vivo, leads to a clinical picture similar to MLD although ASA activity is normal (Schlote et al. 1991). In contrast to the human disease, the mouse model of MLD shows no demyelination (Hess et al. 1996). Enzyme replacement therapy has been successfully evaluated in the animal model: In ASA knockout mice, intravenous ASA injection restored sulfatide metabolism in peripheral tissues and the central nervous system (Matzner et al. 2005). The related disease multiple sulfatase deficiency is caused by a defective formation of a formylglycine residue in the active sites of all sulfatases (Dierks et al. 2005). 


\section{FARBER DISEASE}

Farber disease is a rare ceramide storage disease caused by the inherited deficiency of lysosomal acid ceramidase (AC). AC is a heterodimeric enzyme composed of two subunits (Bernardo et al. 1995), which are derived from a common precursor that is processed within late endosomes and lysosomes (Koch et al. 1996; Shtraizent et al. 2008). AC catalyses the degradation of ceramide to sphingosine and a fatty acid in the lysosomes, the reaction requires the presence of Sap-D (Klein et al. 1994). The enzyme is also able to catalyze the reverse reaction (Okino et al. 2003). The most characteristic clinical manifestation is the development of painful and progressive joint deformations, subcutaneous nodules (lipogranulomas), and progressive hoarseness. AC is an essential factor required for embryonic survival. AC knockout mice do not survive beyond the 2-cell stage and undergo apoptotic death (Eliyahu et al. 2007). Recent findings show that $\mathrm{AC}$ improves the quality of oocytes and embryos and the outcome of in vitro fertilization (Eliyahu et al. 2010).

\section{SPHINGOLIPID AND MEMBRANE STORAGE CAUSED BY DEFECTIVE LLBP}

\section{Prosaposin-Deficiency}

The prosaposin deficiency is a fatal perinatal sphingolipid and membrane storage disorder characterized by hepatosplenomegaly and severe neurological symptoms. Prosaposin, a $70 \mathrm{kDa}$ glycoprotein, is proteolytically processed to four lipid-binding proteins, the mature activator proteins Sap-A-D in the late endosomes and lysosomes (Fürst et al. 1988; Kolter and Sandhoff 2005). Prosaposin is intracellularly targeted to the lysosomes via mannose6-phosphate receptors and sortilin. Rare mutations in the start codon of the prosaposin gene lead to a complete deficiency of the protein and of all four mature saposins (Schnabel et al. 1992; Bradova et al. 1993). Prosaposin deficiency in human patients and mice causes simultaneous storage of many sphingolipids, including ceramide, glucosylceramide, lactosylceramide, ganglioside GM3, galactosylceramide, sulfatides, digalactosylceramide, and globotriaosylceramide, accompanied by a massive accumulation of intralysosomal membranes (Fujita et al. 1996). In cultured fibroblasts, the lipid storage can be completely reversed by treatment with human prosaposin, as demonstrated in prosaposin deficient fibroblasts (Burkhardt et al. 1997).

\section{Sap-A}

Sap-A is required for the degradation of galactosylceramide by galactosylceramide- $\beta$-galactosidase. Genetically engineered mice and patients that carry a mutation in the saposin A-domain of the saposin precursor accumulate galactosylceramide and suffer from a late-onset variant of Krabbe disease (Matsuda et al. 2001).

\section{Sap-B}

Sap-B was the first activator protein identified, and was called the sulfatide-activator (Mehl and Jatzkewitz 1964). It mediates the degradation of sulfatide by arylsulfatase A, globotriaosylceramide and digalactosylceramide by $\alpha$ galactosidase $\mathrm{A}$, as well as other glycolipids, (e.g., ganglioside GM2 together with the GM2activator protein) (Wilkening et al. 2000). Glycosylated saposins bind to lipid bilayers in vitro at acidic $\mathrm{pH}$ and are able to extract lipids.

\section{Sap-C}

Sap-C was initially isolated from the spleen of patients with Gaucher disease (Ho and O'Brien 1971). It is required for the lysosomal degradation of glucosylceramide by glucosylceramide$\beta$-glucosidase (Alattia et al. 2007). Sap-C deficiency leads to an abnormal juvenile form of Gaucher disease with an accumulation of glucosylceramide (Schnabel et al. 1991).

\section{Sap-D}

Sap-D stimulates lysosomal ceramide degradation by acid ceramidase. It is able to bind to vesicles containing negatively charged lipids and to solubilize them at an appropriate $\mathrm{pH}$ (Ciaffoni et al. 2001). Saposin D-deficient 
H. Schulze and K. Sandhoff

mice accumulate ceramides with hydroxylated fatty acids mainly in the brain and in the kidney (Matsuda et al. 2004).

\section{NIEMANN-PICK DISEASE TYPE C}

Niemann-Pick disease type C (NPC) is a complex neurodegenerative lipid storage disease characterized by the accumulation of unesterified cholesterol and a broad range of other lipids in the late endolysosomal compartment (Patterson et al. 2001). The disease is caused by mutations in either of the genes of the NPC1 or the NPC2 protein, which leads to impaired cholesterol transport out of the late endosomes. Cells can take up cholesterol via receptor mediated endocytosis, (e.g., of low-density lipioprotein (LDL) rich in cholesteryl ester). In the endosomal compartments, cholesteryl esters are hydrolyzed by cholesterol esterase to fatty acid and cholesterol (Brown and Goldstein 1986). The cholesterol is not degraded in the lysosome, but is rapidly transported out of the late endosome to induce homeostatic responses by downward regulation of the de novo synthesis of the LDL-receptor, thus regulating the cellular cholesterol uptake and de novo synthesis of cholesterol (Ikonen 2008). Transport of cholesterol from the endosomal system requires two cholesterol-binding proteins, Niemann-Pick C1 (NPC1) and Niemann-Pick C2 (NPC2) (Infante et al. 2008). $\mathrm{NPC1}$ is a late endolysosomal glycoprotein with 13 transmembrane domains (Carstea et al. 1997). NPC2 is a glycosylated, soluble protein (Naureckine et al. 2000). In a proposed model (Abdul-Hammed et al. 2010; Gallala et al. 2010), soluble NPC2 removes cholesterol from inner endosomal/lysosomal vesicles and delivers it to NPC1 in the limiting membrane of endosomes/lysosomes for cholesterol egress from the late endocytic compartments (Karten et al. 2009; Storch and Xu 2009) (Fig. 4). Liver and brain of NPC patients show accumulation of cholesterol in the late endosomes and lysosomes. Additionally, sphingomyelin, neutral glycolipids (e.g., glucosylceramide, lactosylceramide), gangliosides GM3 and GM2 (Zervas et al. 2001a; teVruchte et al. 2004), BMP (Kobayashi et al. 1999), and sphingosine (RodriguezLafrasse et al. 1994) also accumulate. This secondary storage can be explained by a type of traffic jam that occurs in the late endosomal compartments when lipids such as cholesterol accumulate and might contribute to the clinical features associated with each lysosomal storage disorder (Simons and Gruenberg 2000) as increasing cholesterol levels have an inhibitory

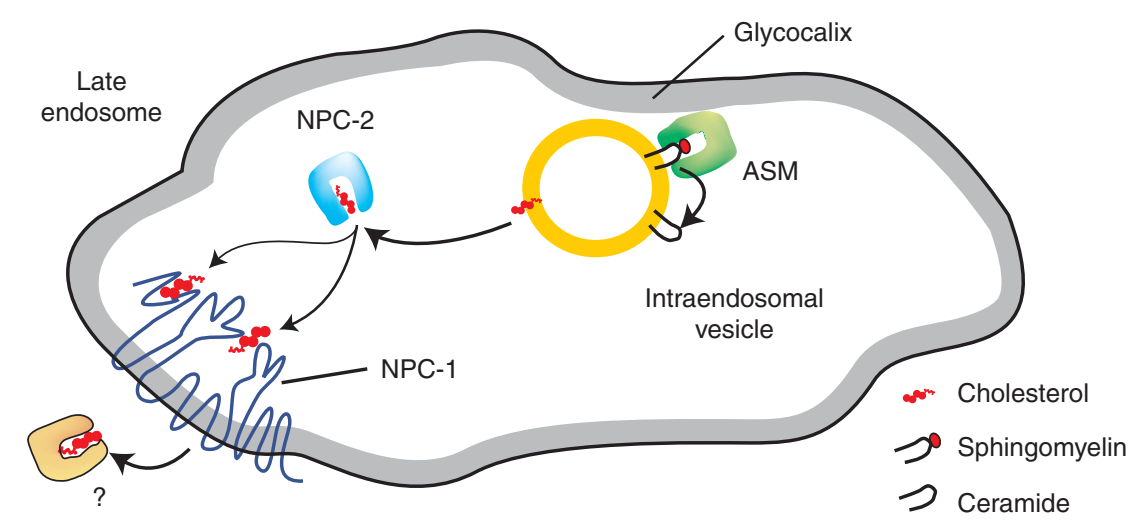

Figure 4. Proposed model for lipid sorting at the stage of late endosomes. At the surface of intraendosomal vesicles acid sphingomyelinase degrades sphingomyelin to ceramide. The resulting decrease of sphingomyelin and the increase of ceramide levels stimulate the removal of cholesterol from BMP containing inner endosomal vesicles and its transfers to NPC1 in the limiting membrane of the late endosome (Infante et al. 2008). NPC1 mediates cholesterol egress through the glycocalyx (adapted from Abdul-Hammed et al. [2010] and reprinted with permission from the American Society for Biochemisty and Molecular Biology (C) 2010). 
effect on the activity of some lysosomal lipid binding and transfer proteins such as Sap-A and -B (Locatelli-Hoops et al. 2006; Remmel et al. 2007). NPC1-mutant cells show a substantial reduction of the calcium levels in the acidic compartment (Lloyd-Evans et al. 2008). Furthermore, cholesterol levels are increased in the cell bodies of cultured murine neurons lacking functional NPC1 and are decreased in their distal axons. This altered cholesterol distribution suggests that transport of endogenously synthesized cholesterol, from cell bodies to distal axons is impaired in NPC1-deficient neurons (Karten et al. 2002, 2003).

\section{WOLMAN DISEASE AND CHOLESTERYL ESTER STORAGE DISEASE}

Deficiency of lysosomal acid lipase (LAL, also called acid cholesteryl ester hydrolase) leads either to Wolman disease or to the less severe cholesteryl ester storage disease (CESD) (Assmann and Seedorf 2001). Wolman disease is nearly always fatal in infancy, whereas CESD may go undetected until adulthood. In contrast to CESD, the more severe course of Wolman disease is caused by genetic defects of LAL that leave no residual enzyme activity (Aslanidis 1996). These diseases follow an autosomal recessive mode of inheritence. LAL hydrolyzes a variety of substrates such as cholesteryl esters and triglycerides, which are the main lipid storage material. There is no specific treatment available. Bone marrow transplantation might preserve the hepatic and cognitive functions of Wolman disease patients (Krivit et al. 2000; Tolar et al. 2009), although success seems to be inconsistent (Gramatges et al. 2009). Enzyme replacement and gene therapy have been applied to LAL deficient mice (Tietge et al. 2001; Du et al. 2008).

\section{THERAPEUTIC APPROACHES}

In addition to symptomatic treatment, therapies addressing the underlying metabolic defect of LLSD have been in development over the last three decades. Therapies include enzyme replacement therapy (ERT), bone marrow transplantation (BMT), hematopoietic stem cell transplantation, gene therapy, enzyme stabilization, and substrate reduction therapy (Platt and Lachmann 2009). Enzyme replacement was first developed for the adult nonneuronopathic form of Gaucher disease (Barton et al. 1990). Glucosylceramide- $\beta$-glucosidase (glucocerebrosidase), purified from human placenta, was modified in the carbohydrate part to contain targeting information for the mannose receptor on macrophages such as Kupffer cells (Barton et al. 1990). Today, ERT with recombinant enzymes is available for Gaucher and Fabry disease. ERT is restricted to the nonneuronopathic forms of the diseases, because the proteins cannot pass the blood-brain barrier. However, ERT alleviated CNS storage in an arylsulfatase A knockout mouse model of metachromatic leukodystrophy (Matzner et al. 2005). Allogenic BMT has been used in a multiplicity of lysosomal sphingolipid storage diseases. Early BMT can even halt neurodegeneration in some cases as described for Wolman disease (Krivit et al. 1999). Microglial cells producing the deficient enzyme in the brain derive from stem cells from the donor bone marrow.

Gene therapy to target the central nervous system has been evaluated in the animal models of some lysosomal storage diseases such as Gaucher disease (Enquist et al. 2006), metachromatic leukodystrophy (Biffi et al. 2006), and Tay-Sachs disease (Cachón-González et al. 2006).

Enzyme stabilization, or pharmacological chaperone therapy, is based on the application of small molecules that enhance folding or prevent premature degradation of the defective enzyme. Lysosomal storage diseases are suitable candidates for enzyme stabilization treatment, as the levels of enzyme activity needed to prevent substrate storage are often relatively low (Fan 2008).

In substrate reduction therapy, the glucosylceramide synthase inhibitor $N$-butyldeoxynojirimycin is used to reduce GSL biosynthesis, thus lowering the amount of accumulated GSL in the lysosome (Platt et al. 1994; Platt and Butters 2004). Possible residual activity might then 
be able to cope with the smaller GSL load. In clinical trials, substrate reduction therapy for type 1 Gaucher patients was effective (Elstein et al. 2004) and studies on mouse models of Tay-Sachs (Platt et al. 1997), Sandhoff (Jeyakumar et al. 1999), Fabry (Heare et al. 2007), GM1 gangliosidosis (Elliot-Smith et al. 2008), and NPC (Zervas et al. 2001b) demonstrated the usefulness of this approach in a wide range of lysosomal lipid storage diseases (Lachmann and Platt 2001).

\section{ACKNOWLEDGMENTS}

We thank Natascha Remmel, Hichem Galalla, and Thomas Kolter for their critical comments. Work performed in the laboratory of the authors was supported by grants from the German Research Foundation (DFG): SFB 645, SFB TRR 83, SPP Sphingolipids-Signaling and Disease.

\section{REFERENCES}

Abdul-Hammed M, Breiden B, Adebayo MA, Babalola JA, Schwarzmann G, Sandhoff K. 2010. The roles of endosomal membrane lipids and NPC2 in cholesterol transfer and membrane fusion. J Lipid Res 51: 1747-60.

Alattia JR, Shaw JE, Yip CM, Privé GG. 2007. Molecular imaging of membrane interfaces reveals mode of $\beta$-glucosidase activation by saposin C. Proc Natl Acad Sci 104: 17394-17399.

Amidon B, Brown A, Waite M. 1996. Transacylase phospholipases in the synthesis of bis(monoacylglycero)phosphate. Biochemistry 35: 13995-14002.

Assmann G, Seedorf U. 2001. Acid lipase deficiency: Wolman disease and cholesteryl ester storage disease. In The metabolic and molecular bases of inherited disease (ed. C.R. Scriver, et al.), pp. 3551-3572. McGraw-Hill, New York.

Aslanidis C, Ries S, Fehringer P, Büchler C, Klima H, Schmitz G. 1996. Genetic and biochemical evidence that CESD and Wolman disease are distinguished by residual lysosomal acid lipase activity. Genomics 33: 85-93.

Barton NW, Brady RO, Dambrosia JM, Di Bisceglie AM, Doppelt SH, Hill SC, Mankin HJ, Murray GJ, Parker RI, ArgoffCE, et al. 1991. Replacement therapy for inherited enzyme deficiency - macrophage-targeted glucocerebrosidase for Gaucher's disease. N Engl J Med 324: 1464-1470.

Barton NW, Furbish FS, Murray GJ, Garfield M, Brady RO. 1990. Therapeutic response to intravenous infusions of glucocerebrosidase in a patient with Gaucher disease. Proc Natl Acad Sci 87: 1913-1916.

Bejaoui K, Uchida Y, Yasuda S, Ho M, Nishijima M, Brown RHJR, Holleran WM, Hanada K. 2002. Hereditary sensory neuropathy type 1 mutations confer dominant negative effects on serine palmitoyltransferase, critical for sphingolipid synthesis. J Clin Invest 110: 1301-1308.

Bernardo K, Hurwitz R, Zenk T, Desnick RJ, Ferlinz K, Schuchman EH, Sandhoff K. 1995. Purification, characterization, biosynthesis of human acid ceramidase. J Biol Chem 270: 11098-11102.

Beutler E, Grabowski GA. 2001. Gaucher Disease. In The metabolic and molecular bases of inherited disease, 8th ed. (ed. C. Scriver, et al.), pp. 3635-3668. McGraw-Hill, New York.

Bi X, Liao G. 2010. Cholesterol in Niemann-Pick Type C disease. Subcell Biochem 51: 319-35.

Biffi A, Capotondo A, Fasano S, del Carro U, Marchesini S, Azuma H, Malaguti MC, Amadio S, Brambilla R, Grompe M, et al. 2006. Gene therapy of metachromatic leukodystrophy reverses neurological damage and deficits in mice. J Clin Invest 116: 3070-3082.

Bradova V, Smid F, Ulrich-Bott B, Roggendorf W, Paton BC, Harzer K. 1993. Prosaposin deficiency: Further characterization of the sphingolipid activator protein-deficient sibs. Multiple glycolipid elevations (including lactosylceramidosis), partial enzyme deficiencies ultrastructure of the skin in this generalized sphingolipid storage disease. Hum Genet 92: 143-152.

Brady RO. 2006. Enzyme replacement for lysosomal diseases. Annu Rev Med 57: 28-296.

Brotherus J, Renkonen O. 1977. Subcellular distributions of lipids in cultured BHK cells: Evidence for the enrichment of lysobisphosphatidic acid neutral lipids in lysosomes. $J$ Lipid Res 18: 191-202.

Brown M, Goldstein J. 1986. A receptor-mediated pathway for cholesterol homeostasis. Science 232: 34-47.

Burkhardt JK, Hüttler S, Klein A, Möbius W, Habermann A, Griffiths G, Sandhoff K. 1997. Accumulation of sphingolipids in SAP-precursor (prosaposin)-deficient fibroblasts occurs as intralysosomal membrane structures and can be completely reversed by treatment with human SAP-precursor. Eur J Cell Biol 73: 10-18.

Cachón-González MB, Wang SZ, Lynch A, Ziegler R, Cheng SH, Cox TM. 2006. Effective gene therapy in an authentic model of Tay-Sachs-related diseases. Proc Natl Acad Sci 103: $10373-10378$.

Carstea ED, Morris JA, Coleman KG, Loftus SK, Zhang D, Cummings C, Gu J, Rosenfeld MA, Pavan WJ, Krizman DB, et al. 1997. Niemann-Pick C1 disease gene: homology to mediators of cholesterol homeostasis. Science 277: $228-231$.

Chojnacki T, Dallner G. 1988. The biological role of dolichol. Biochem J 251: 1-9.

Ciaffoni F, Salvioli R, Tatti M, Arancia G, Crateri P, Vaccaro AM. 2001. Saposin D solubilizes anionic phospholipidcontaining membranes. J Biol Chem 276: 31583-31589.

Conzelmann E, Sandhoff K. 1979. AB variant of infantile GM2 gangliosidosis: Deficiency of a factor necessary for stimulation of hexosaminidase A-catalyzed degradation of ganglioside GM2 glycolipid GA2. Proc Natl Acad Sci 75: 3979-3983.

Conzelmann E, Sandhoff K. 1983-1984. Partial enzyme deficiencies: Residual activities and the development of neurological disorders. Dev Neurosci 6: 58-71. 
Dawkins JL, Hulme DJ, Brahmbhatt SB, Auer-Grumbach M, Nicholson GA. 2001. Mutations in SPTLC1, encoding serine palmitoyltransferase, long chain base subunit-1, cause hereditary sensory neuropathy type I. Nat Genet 27: $309-312$.

de Duve C. 2005. The lysosome turns fifty. Nat Cell Biol 7: 847-849.

Desnick RJ, Ioannou YA. 2001. $\alpha$-Galactosidase a deficiency fabry disease. In The metabolic and molecular bases of inherited disease, 8th ed. (ed. C.R. Scriver, et al.), pp. 3733-3774. McGraw-Hill, New York.

Dierks T, Dickmanns A, Preusser-Kunze A, Schmidt B, Mariappan M, von Figura K, Ficner R, Rudolph MG. 2005. Molecular basis for multiple sulfatase deficiency and mechanism for formylglycine generation of the human formylglycine-generating enzyme. Cell 121: $541-552$.

Dong XP, Cheng X, Mills E, Delling M, Wang F, Kurz T, Xu H. 2008. The type IV mucolipidosis-associated protein TRPML1 is an endolysosomal iron release channel. Nature 455: 992-996.

Du H, Cameron TL, Garger SJ, Pogue GP, Hamm LA, White E, Hanley KM, Grabowski GA. 2008. Wolman disease/ cholesteryl ester storage disease: Efficacy of plant-produced human lysosomal acid lipase in mice. J Lipid Res 49: 1646-1657.

Du H, Schiavi S, Levine M, Mishra J, Heur M, Grabowski GA. 2001. Enzyme therapy for lysosomal acid lipase deficiency in the mouse. Hum Mol Genet 16: 1639-1648.

Elliot-Smith E, Speak AO, Lloyd-Evans E, Smith DA, van der Spoel AC, Jeyakumar M, Butters TD, Dwek RA, d'Azzo A, Platt FM. 2008. Beneficial effects of substrate reduction therapy in a mouse model of GM1 gangliosidosis. Molec Genet Metab 94: 204-211.

Eliyahu E, Park JH, Shtraizent N, He X, Schuchman EH. 2007. Acid ceramidase is a novel factor required for early embryo survival. FASEB J 21: 1403-1409.

Eliyahu E, Shtraizent N, Martinuzzi K, Barritt J, He X, Wei H, Chaubal S, Copperman AB, Schuchman EH. 2010. Acid ceramidase improves the quality of oocytes and embryos and the outcome of in vitro fertilization. FASEB J 24: $1229-1238$.

Elstein D, Hollak C, Aerts JM, van Weely S, Maas M, Cox TM, Lachmann RH, Hrebicek M, Platt FM, Butters TD, et al. 2004. Sustained therapeutic effects of oral miglustat (Zavesca, $N$-butyldeoxynojirimycin, OGT 918) in type I Gaucher disease. J Inherit Meta Dis 27: 757-766.

Enquist IB, Nilsson E, Ooka A, Månsson JE, Olsson K, Ehinger M, Brady RO, Richter J, Karlsson S. 2006. Effective cell and gene therapy in a murine model of Gaucher disease. Proc Natl Acad Sci 103: 13819-13824.

Eskelinen EL, Tanaka Y, Saftig P. 2003. At the acidic edge: Emerging functions for lysosomal membrane proteins. Trends Cell Biol 13: 137-145.

Fan JQ. 2008. A counterintuitive approach to treat enzyme deficiencies: Use of enzyme inhibitors for restoring mutant enzyme activity. Biol Chem 389: 1-11.

Ferlinz K, Hurwitz R, Sandhoff K. 1991. Molecular basis of acid sphingomyelinase deficiency in a patient with Niemann-Pick disease type A. Biochem Biophys Res Commun 179: 1187-1191.
Ferlinz K, Hurwitz R, Weiler M, Suzuki K, Sandhoff K, Vanier MT. 1995. Molecular analysis of the acid sphingomyelinase deficiency in a family with an intermediate form of Niemann-Pick disease. Am J Hum Genet 56: 1343-1349.

Filho JAF, Shapiro BE. 2004. Tay Sachs disease. Arch Neurol 61: 466-468.

Fürst W, Sandhoff K. 1992. Activator proteins topology of lysosomalsphingolipid catabolism. Biochim. Biophys Acta 1126: 1-16.

Fürst W, Machleidt W, Sandhoff K. 1988. The precursor of sulfatide activator protein is processed to three different proteins. Biol Chem Hoppe Seyler 369: 317-328.

Fujita N, Suzuki K, Vanier MT, Popko B, Maeda N, Klein A, Henseler M, Sandhoff K, Nakayasu H. 1996. Targeted disruption of the mouse sphingolipid activator protein gene: A complex phenotype, including severe leukodystrophy and wide-spread storage of multiple sphingolipids. Hum Mol Genet 5: 711-725.

Gallala HD, Breiden B, Sandhoff K. 2011. Regulation of the NPC2 protein-mediated cholesterol trafficking by membrane lipids. J Neurochem 116: 702-707.

Gieselmann V. 2005. What can cell biology tell us about heterogeneity in lysosomal storage diseases? Acta Paediatr Suppl 94: 80-86.

Gieselmann V. 2008. Metachromatic leukodystrophy: genetics, pathogenesis and therapeutic options. Acta Paediatr Suppl 97: 15-21.

Gillard BK, Clement RG, Marcus DM. 1998. Variations among cell lines in the synthesis of sphingolipids in de novo and recycling pathways. Glycobiology 8: 885-890.

Gramatges MM, Dvorak CC, Regula DP, Enns GM, Weinberg K, Agarwal R. 2009. Pathological evidence of Wolman's disease following hematopoietic stem cell transplantation despite correction of lysosomal acid lipase activity. Bone Marrow Transplant 44: 449-450.

Gravel RA, Kaback MM, Proia RL, Sandhoff K, Suzuki K, Suzuki K. 2001. The GM2 Gangliosidoses. In The metabolic and molecular bases of inherited disease, 8th ed. Vol. III (ed. C.R. Scriver, et al.), pp. 3827-3876. McGrawHill, New York.

Hahn CN, del Pilar Martin M, Schroder M, Vanier MT, Hara Y, Suzuki K, d'Azzo A. 1997. Generalized CNS disease massive GM1-ganglioside accumulation in mice defective in lysosomal acid $\beta$-galactosidase. Hum Mol Genet 6: $205-211$.

Hanada K, Kumagai K, Yasuda S, Miura Y, Kawano M, Fukasawa M, Nishijima M. 2003. Molecular machinery for non-vesicular trafficking of ceramide. Nature 426: 803-809.

Harzer K, Paton BC, Poulos A, Kustermann-Kuhn B, Roggendorf W, Grisar T, Popp M. 1989. Sphingolipid activator protein deficiency in a 16-week-old atypical Gaucher disease patient his fetal sibling: Biochemical signs of combined sphingolipidoses. Eur J Pediatr 149: 31-39.

Heare T, Alp NJ, Priestman DA, Kulkarni AB, Qasba P, Butters TD, Dwek RA, Clarke K, Channon KM, Platt FM. 2007. Severe endothelial dysfunction in the aorta of a mouse model of Fabry disease; partial prevention by $N$-butyldeoxynojirimycin treatment. I Inherit Metab Dis 30: 79-87. 
H. Schulze and K. Sandhoff

Hers HG. 1963. $\alpha$-Glucosidase deficiency in generalized glycogenstorage disease (Pompe's disease). Biochem $\mathrm{Jl}$ 86: $11-16$

Hess B, Saftig P, Hartmann D, Coenen R, Lullmann-Rauch R, Goebel HH, Evers M, von Figura K, D'Hooge R, Nagels G, et al. 1996. Phenotype of arylsulfatase A-deficient mice: Relationship to human metachromatic leukodystrophy. Proc Natl Acad Sci 93: 14821-14826.

Ho MW, O’Brien JS. 1971. Gaucheŕs disease: Deficiency of "acid"-glucosidase and reconstitution of enzyme activity in vitro. Proc Natl Acad Sci 68: 2810-2813.

Ikonen E. 2008. Cellular cholesterol trafficking and compartmentalization. Nat Rev Mol Cell Biol 9: 125-138.

Infante RE, Wang ML, Radhakrishnan A, Kwon HJ, Brown MS, Goldstein JL. 2008. NPC2 facilitates bidirectional transfer of cholesterol between NPC1 and lipid bilayers, a step in cholesterol egress from lysosomes. Proc Nat Acad Sci 105: 15287-15292.

Jeyakumar M, Williams I, Smith D, Cox TM, Platt FM. 2009. Critical role of iron in the pathogenesis of the murine gangliosidoses. Neurobiol Di 34: 406-416.

Jeyakumar M, Butters TD, Cortina-Borja M, Hunnam V, Proia RL, Perry VH, Dwek RA, Platt FM. 1999. Delayed symptom onset and increased life expectancy in Sandhoff disease mice treated with $\mathrm{N}$-butyldeoxynojirimycin, Proc Natl Acad Sci 96: 6388-6393.

Jmoudiak M, Futerman AH. 2005. Gaucher disease: pathological mechanisms and modern management. BrJ Haematol 129: $178-188$.

Karten B, Peake KB, Vance JE. 2009. Mechanisms and consequences of impaired lipid trafficking in Niemann-Pick type C1-deficient mammalian cells. Biochim Biophys Acta 1791: 659-670.

Karten B, Vance DE, Campenot RB, Vance JE. 2002. Cholesterol accumulates in cell bodies, but is decreased in distal axons of Niemann-Pick C1-deficient neurons. J Neurochem 83: 1154-1163.

Karten B, Vance DE, Campenot RB, Vance JE. 2003. Trafficking of cholesterol from cell bodies to distal axons in Niemann Pick C1-deficient neurons. J Biol Chem 278: 4168-4875.

Kirkegaard T, Roth AG, Petersen NH, Mahalka AK, Olsen OD, Moilanen I, Zylicz A, Knudsen J, Sandhoff K, Arenz C, et al. 2010. Hsp70 stabilizes lysosomes and reverts Niemann-Pick disease-associated lysosomal pathology. Nature 463: 549-553.

Klein A, Henseler M, Klein C, Suzuki K, Harzer K, Sandhoff K. 1994. Sphingolipid activator protein D (sap-D) stimulates the lysosomal degradation of ceramide in vivo. Biochem Biophys Res Commun 200: 1440-1448.

Kobayashi T, Beuchat MH, Lindsay M, Frias S, Palmiter RD, Sakuraba H, Parton RG, Gruenberg J. 1999. Late endosomal membranes rich in lysobisphosphatidic acid regulate cholesterol transport. Nat Cell Biol 1: 113-118.

Kobayashi T, Stang E, Fang KS, de Moerloose P, Parton RG, Gruenberg J. 1998. A lipid associated with the antiphospholipid syndrome regulates endosome structure function. Nature 392: 193-197.

Koch J, Gärtner S, Li CM, Quintern LE, Bernardo K, Levran O, Schnabel D, Desnick RJ, Schuchman EH, Sandhoff K. 1996. Molecular cloning characterization of a full-length complementary DNA encoding human acid ceramidase. Identification of the first molecular lesion causing Farber disease. J Biol Chem 271: 33110-33115.

Kölzer M, Werth N, Sandhoff K. 2004. Interaction of acid sphingomyelinase and lipid bilayers in the presence of tricyclic antidepressant desipramine. FEBS Lett 559: 96-98.

Kolter T, Sandhoff K. 1999. Sphingolipids-Their metabolic pathways the pathobiochemistry of neurodegenerative diseases. Angew Chem In Ed 38: 1532-1568.

Kolter T, Sandhoff K. 2005. Principles of lysosomal membrane digestion: stimulation of sphingolipid degradation by sphingolipid activator proteins and anionic lysosomal lipids. Annu Rev Cell Dev Biol 21: 81-103.

Kolter T, Sandhoff K. 2006. Sphingolipid metabolism diseases. Biochim Biophys Acta 1758: 2057-2079.

Kolter T, Sandhoff K. 2010. Lysosomal degradation of membrane lipids. FEBS Lett 584: 1700-1712.

Komatsu M, Waguri S, Chiba T, Murata S, Iwata J, Tanida I, Ueno T, Koike M, Uchiyama Y, Kominami E, et al. 2006. Loss of autophagy in the central nervous system causes neurodegeneration in mice. Nature 441: 880-884.

Krivit W, Peters C, Shapiro EG. 1999. Bone marrow transplantation as effective treatment of central nervous system disease in globoid cell leukodystrophy, metachromatic leukodystrophy, adrenoleukodystrophy, mannosidosis, fucosidosis, aspartylglucosaminuria, Hurler, Maroteaux-Lamy, and Sly syndromes, and Gaucher disease type III. Curr Opin Neurol 12: 167-176.

Krivit W, Peters C, Dusenbery K, Ben-Yoseph Y, Ramsay NK, Wagner JE, Anderson R. 2000. Wolman disease successfully treated by bone marrow transplantation. Bone Marrow Transplant 26: $567-570$.

Kurz T, Terman A, Gustafsson B, Brunk UT. 2008. Lysosomes in iron metabolism, ageing and apoptosis. Histochem Cell Biol 129: 389-406.

Kytzia HJ, Sandhoff K. 1985. Evidence for two different active sites on human $\beta$-hexosaminidase $A$. Interaction of GM2 activator protein with $\beta$-hexosaminidase A. $J$ Biol Chem 260: 7568-7572.

Lachmann RH, Platt FM. 2001. Substrate reduction therapy for glycosphingolipid storage disorders. Expert Opin Investig Drugs 10: 455-466.

Lansmann S, Schuette CG, Bartelsen O, Hoernschemeyer J, Linke T, Weisgerber J, Sandhoff K. 2003. Human acid sphingomyelinase. Eur J Biochem 270: 1076-1088.

LaPlante JM, Ye P, Quinn SJ, Goldin E, Brown EM, Slaugenhaupt SA, Vassilev PM. 2002. Identification and characterization of the single channel function of human mucolipin-1 implicated in mucolipidosis type IV, a disorder affecting the lysosomal pathway. FEBS Lett 532: $183-187$.

Leinekugel P, Michel S, Conzelmann E, Sandhoff K. 1992. Quantitative correlation between the residual activity of $\beta$-hexosaminidase $A$ and arylsulfatase $A$ and the severity of the resulting lysosomal storage disease. Hum Genet 88: $513-523$.

Linhart A, Elliot PM. 2007. The heart in Anderson-Fabry disease and other lysosomal storage disorders. Heart 93: $528-535$. 
Liu K, Commens C, Choong R, Jaworski R. 1988. Collodion babies with Gaucher's disease. Arch Dis Child 63: 854856.

Lloyd-Evans E, Platt FM. 2010. Lipids on trial: The search for the offending metabolite in Niemann-Pick type C disease. Traffic 11: 419-428.

Lloyd-Evans E, Morgan AJ, He X, Smith DA, Elliot-Smith E, Sillence DJ, Churchill GC, Schuchman EH, Galione A, Platt FM. 2008. Niemann-Pick disease type $\mathrm{C} 1$ is a sphingosine storage disease that causes deregulation of lysosomal calcium. Nat Med 14: 1247-1255.

Locatelli-Hoops S, Remmel N, Klingenstein R, Breiden B, Rossocha M, Schoeniger M, Koenigs C, Saenger W, Sandhoff K. 2006. Saposin A mobilizes lipids from low cholesterol and high bis(monoacylglycerol)phosphatecontaining membranes: Patient variant Saposin A lacks lipid extraction capacity. J Biol Chem 281: 32451-32460.

Matzner U, Herbst E, Hedayati KK, Lüllmann-Rauch L, Wessig C, Schröder S, Eistrup C, Möller C, Fogh J, Gieselmann V. 2005. Enzyme replacement improves nervous system pathology and function in a mouse model for metachromatic leukodystrophy. Hum Mol Genet 14: $1139-1152$.

Matsuda J, Kido M, Tadano-Aritomi K, Ishizuka I, Tominaga K, Toida K, Takeda E, Suzuki K, Kuroda Y. 2004 Mutation in saposin D domain of sphingolipid activator protein gene causes urinary system defects and cerebellar Purkinje cell degeneration with accumulation of hydroxy fatty acid-containing ceramide in mouse. Hum Mol Genet 13: $2709-2723$.

Matsuda J, Vanier MT, Saito Y, Tohyama J, Suzuki K. 2001 A mutation in the saposin A domain of the sphingolipid activator protein (prosaposin) gene results in a lateonset, chronic form of globoid cell leukodystrophy in the mouse. Hum Mol Gene 10: 1191-1199.

Matsuzawa Y, Hostetler KY. 1979. Degradation of bis(monoacylglycero)phosphate by an acid phosphodiesterase in rat liver lysosomes. J Biol Chem 254: 5997-6001.

Merrill AH Jr. 2002. De novo sphingolipid biosynthesis: A necessary, but dangerous pathway. J Biol Chem 277: 25843-25846

Mehl E, Jatzkewitz H. 1964. A cerebrosidesulfatase from swine kidney. Hoppe Seylers Z Physiol Chem 339: 260-276.

Mehl E, Jatzkewitz H. 1965. Evidence for the genetic block in metachromatic leukodystrophy (ML). Biochem biophys Res Commun 19: 407-411.

Meivar-Levy I, Horowitz M, Futerman AH. 1994. Analysis of glucocerebrosidase activity using $\mathrm{N}-(1-[14 \mathrm{C}]$ hexanoyl)-d-erythroglucosylsphingosine demonstrates a correlation between levels of residual enzyme activity the type of Gaucher disease. Biochem J 303: 377-382.

Möbius W, van Donselaar E, Ohno-Iwashita Y, Shimada Y, Heijnen HF, Slot JW, Geuze HJ. 2003. Recycling compartments and the internal vesicles of multivesicular bodies harbor most of the cholesterol found in the endocytic pathway. Traffic 4: 222-231.

Naureckiene S, Sleat DE, Lackland H, Fensom A, Vanier MT, Wattiaux R, Jadot M, Lobel P. 2000. Identification of HE1 as the second gene of Niemann-Pick C disease. Science 290: $2298-2301$.
Neuenhofer S, Conzelmann E, Schwarzmann G, Egge H Sandhoff K. 1986. Occurrence of lysoganglioside lysoGM2 (II3-Neu5Ac-gangliotriaosylsphingosine) in GM2 gangliosidosis brain. Biol Chem Hoppe Seyler 367: 241-244.

Okino N, He X, Gatt S, Sandhoff K, Ito M, Schuchman EH. 2003. The reverse activity of human acid ceramidase. J Biol Chem 278: 29948-29953.

Pastores GM. 2009. Krabbe disease: An overview. Int J Clin Pharmacol Ther 47: 75-81.

Patterson MC, Vanier MT, Suzuki K, Morris JA, Carsteu E, Neufeld EB, et al. 2001. Niemann-Pick disease type C. A lipid trafficking disorder. In The metabolic and molecular basis of inherited disease, Vol. II, 8th ed. (ed. C.R. Scriver, et al.), pp. 3611-3633. McGraw-Hill, New York.

Pelled D, Lloyd-Evans E, Riebeling C, Jeyakumar M, Platt FM, Futerman AH. 2003. Inhibition of calcium uptake via the sarco/endoplasmic reticulum $\mathrm{Ca}^{2+}$-ATPase in a mouse model of Sandhoff disease and prevention by treatment with $\mathrm{N}$-butyldeoxynojirimycin. J Biol Chem 278: $29496-29501$.

Penno A, Reilly MM, Houlden H, Laurá M, Rentsch K, Niederkofler V, Stoeckli ET, Nicholson G, Eichler F, Brown RH Jr, et al. 2010. Hereditary sensory neuropathy type 1 is caused by the accumulation of two neurotoxic sphingolipids. J Biol Chem 285: 11178-11187.

Platt FM, Butters TD. 2004. Inhibition of substrate synthesis: A pharmacological approach for glycosphingolipid storage disease therapy. In Lysosomal disorders of the brain (ed. F.M. Platt, et al.), pp. 381-408. Oxford University Press, UK.

Platt F, Lachmann RH. 2009. Treating lysosomal storage disorders: Current practice and future prospects. Biochem Biophys Acta 1793: 737-745.

Platt FM, Neises GR, Dwek RA, Butters TD. 1994. $\mathrm{N}$-butyldeoxynojirimycin is a novel inhibitor of glycolipid biosynthesis. J Biol Chem 269: 8362-8365.

Platt FM, Neises GR, Reinkensmeier G, Townsend MJ, Perry VH, Proia RL, Winchester B, Dwek RA, Butters TD. 1997. Prevention of lysosomal storage in Tay-Sachs mice treated with $N$-butyldeoxynojirimycin. Science 276: $428-431$.

Remmel N, Locatelli-Hoops S, Breiden B, Schwarzmann G, Sandhoff K. 2007. Saposin B mobilizes lipids from cholesterol-poor and bismonoacylglycero)phosphaterich membranes at acidic $\mathrm{pH}$. Unglycosylated patient variant saposin B lacks lipid-extraction capacity. FEBS J 274: 3405-3420.

Rodriguez-Lafrasse C, Rousson R, Pentchev PG, Louisot P, Vanier MT. 1994. Free sphingoid bases in tissues from patients with type C Niemann-Pick disease and other lysosomal storage disorders. Biochim Biophys Acta 1226: $138-144$.

Rosengren B, Fredman P, Mansson JE, Svennerholm L. 1989. Lysosulfatide (galactosylsphingosine-3-O-sulfate) from metachromatic leukodystrophy and normal human brain. J Neurochem 52: 1035-1041.

Ruivo R, Anne C, Sagné C, Gasnier B. 2009. Molecular and cellular basis of lysosomal transmembrane protein dysfunction. Biochim Biophys Acta 1793: 636-649. 
H. Schulze and K. Sandhoff

Rutsch F, Gailus S, Miousse IR, Suormala T, Sagné C, Toliat MR, Nürnberg G, Wittkampf T, Buers I, Sharifi A, et al. 2009. Identification of a putative lysosomal cobalamin exporter altered in the cblF defect of vitamin B12 metabolism. Nat Genet 41: 234-239.

Sagné C, Gasnier B. 2008. Molecular physiology and pathophysiology of lysosomal membrane transporters. JInherit Metab Dis 31: 258-266.

Saksena S, Ji S, Chu T, Emr SD. 2007. ESCRTing proteins in the endocytic pathway. Trends Biochem Sci 23: 519-547.

Sandhoff K. 1969. Variation of $\beta$-N-acetylhexosaminidasepattern in Tay-Sachs disease. FEBS Lett 4: 351-354.

Sandhoff K, Kolter T, Harzer K. 2001. Sphingolipid activator proteins. In The metabolic and molecular bases of inherited disease, 8th ed. (ed. C.R. Scriver, et al.), pp 3371-3388. McGraw-Hill, New York.

Sandhoff K, Harzer K, Wassle W, Jatzkewitz H. 1971. Enzyme alterations lipid storage in three variants of Tay-Sachs disease. J Neurochem 18: 2469-2489.

Sango K, Yamanaka S, Hoffmann A, Okuda Y, Grinberg A, Westphal H, McDonald MP, Crawley JN, Sandhoff K, Suzuki K, et al. 1995. Mouse models of Tay-Sachs and Sandhoff diseases differ in neurologic phenotype and ganglioside metabolism. Nat Genet 11: 170-176.

Sano R, Trindade VM, Tessitore A, d'Azzo A, Vieira MB, Giugliani R, Coelho JC. 2005. G(M1)-ganglioside degradation and biosynthesis in human and murine G(M1)-gangliosidosis. Clin Chim Acta 354: 131-139.

Sarmientos F, Schwarzmann G, Sandhoff K. 1986. Specificity of human glucosylceramide $\beta$-glucosidase towards synthetic glucosylsphingolipids inserted into liposomes. Kinetic studies in a detergent-free assay system. Eur J Biochem 160: 527-535.

Schlote W, Harzer K, Christomanou H, Paton BC, Kustermann-Kuhn B, Schmid B, Seeger J, Beudt U, Schuster I, Langenbeck U. 1991. Sphingolipid activator protein 1 deficiency in metachromatic leucodystrophy with normal arylsulphatase A activity. A clinical, morphological, biochemical, immunological study. Eur J Pediatr 150: 584-591.

Schnabel D, Schröder M, Sandhoff K. 1991. Mutation in the sphingolipid activator protein 2 in a patient with a variant of Gaucher disease. FEBS Lett 284: 57-59.

Schnabel D, Schröder M, Fürst W, Klein A, Hurwitz R, Zenk T, Weber J, Harzer K, Paton BC, Poulos A. 1992. Simultaneous deficiency of sphingolipid activator proteins 1 and 2 is caused by a mutation in the initiation codon of their common gene. J Biol Chem 267: 3312-3315.

Schuchman EH, Desnick RJ. 2001. Niemann-Pick disease types AB.: Acid sphingomyelinasedeficiencies. In The metabolic and molecular bases of inherited disease, 8th ed. (ed. C.R. Scriver, et al.), pp. 3589-3610. McGrawHill, New York.

Shtraizent N, Eliyahu E, Park JH, He X, Shalgi R, Schuchman EH. 2008. Autoproteolytic cleavage and activation of human acid ceramidase. J Biol Chem 283: 1125311259 .

Simons K, Gruenberg J. 2000. Jamming the endosomal system: lipid rafts and lysosomal storage diseases. Trends Cell Biol 10: 459-462.
Simpson MA, Coss H, Proukakis C, Priestman DA, Neville DC, Reinkensmeier G, Wang H, Wiznitzer M, Gurtz K, Verganelaki A, et al. 2004. Infantile-onset symptomatic epilepsy syndrome caused by a homozygous loss-of-function mutation of GM3 synthase. Nat Genet 36: 1225-1229.

Storch J, Xu Z. 2009. Niemann-Pick C2 (NPC2) and intracellular cholesterol trafficking. Biochim Biophys Acta 1791: 671-678.

Suzuki K. 2003. Globoid cell leukodystrophy (Krabbés disease): uUpdate. J Child Neurol 18: 595-603.

Suzuki K, Chen GC. 1968. GM1-gangliosidosis (generalized gangliosidosis) morphology chemical pathology. Pathol Eur 3: 389-408.

Suzuki K, Suzuki Y. 1970. Globoid cell leucodystrophy (Krabbe's disease): Deficiency of galactocerebroside $\beta$-galactosidase. Proc Natl Acad Sci 66: 302-309.

Suzuki Y, Oshima A, Nanba E. 2001. $\beta$-galactosidase deficiency ( $\beta$-galactosidosis): GM1 gangliosidosis and morquio B disease. In The metabolic and molecular bases of inherited disease, 8th ed. (ed. C.R. Scriver, et al.), pp. 3775-3809. McGraw-Hill, New York.

Tafesse FG, Huitema K, Hermansson M, van der Poel S, van den Dikkenberg J, Uphoff A, Somerhariu P, Holthuis JC. 2007. Both sphingomyelin synthases SMS1 and SMS2 are required for sphingomyelin homeostasis and growth in human HeLa cells. J Biol Chem 282: 17537-17547.

Takamura A, Higaki K, Kajimaki K, Otsuka S, Ninomiya H, Matsuda J, Ohno K, Suzuki Y, Nanba E. 2008. Enhanced autophagy and mitochondrial aberrations in murine G(M1)-gangliosidosis. Biochem Biophys Res Commun 367: 616-622.

Tan MA, Fuller M, Zabidi-Hussin ZA, Hopwood JJ, Meikle PJ. 2010. Biochemical profiling to predict disease severity in metachromatic leukodystrophy. Mol Genet Metab 99: $142-148$.

Tanaka A, Ohno K, Sandhoff K, Maire I, Kolodny EH, Brown A, Suzuki K. 1990. GM2-gangliosidosis B1 variant: Analysis of $\beta$-hexosaminidase $\alpha$ gene abnormalities in seven patients. Am J Hum Genet 46: 329-339.

Tay W. 1881. Symmetrical changes in the region of the yellow spot in each eye of an infant. Transactions of the Ophthalmological Society 1: 55-57.

Tessitore A, del P Martin M, Sano R, Ma Y, Mann L, Ingrassia A, Laywell ED, Steindler DA, Hendershot LM, dÁzzo A. 2004. GM1-ganglioside-mediated activation of the unfolded protein response causes neuronal death in a neurodegenerative gangliosidosis. Mol Cell 15: 753-766.

Tettamanti G, Bassi R, Viani P, Riboni L. 2003. Salvage pathways in glycosphingolipid metabolism. Biochimie 85: $423-437$.

Tint GS, Pentchev P, Xu G, Batta AK, Shefer S, Salen G, Honda A. 1998. Cholesterol and oxygenated cholesterol concentrations are markedly elevated in peripheral tissue but not in brain from mice with the Niemann-Pick type C phenotype. J Inherit Metab Dis 21: 853-863.

te Vruchte D, Lloyd-Evans E, Veldman RJ, Neville DC, Dwek RA, Platt FM, van Blitterswijk WJ, Sillence DJ. 2004. Accumulation of glycosphingolipids in Niemann-Pick C disease disrupts endosomal transport. J Biol Chem 279: 26167-26175. 
Tietge UJ, Sun G, Czarnecki S, Yu Q, Lohse P, Du H, Grabowski GA, Glick JM, Rader DJ. 2001. Phenotypic correction of lipid storage and growth arrest in wolman disease fibroblasts by gene transfer of lysosomal acid lipase. Hum Gene Ther 12: 279-289.

Tolar J, Petryk A, Khan K, Bjoraker KJ, Jessurun J, Dolan M, Kivisto T, Charnas L, Shapiro EG, Orchard PJ. 2009. Long-term metabolic, endocrine, and neuropsychological outcome of hematopoietic cell transplantation for Wolman disease. Bone Marrow Transplant 43: 21-27.

Wilkening G, Linke T, Uhlhorn-Dierks G, Sandhoff K. 2000. Degradation of membrane-bound ganglioside GM1, stimulation by bis(monoacylglycero) phosphate the activator proteins SAP-B GM2-AP. J Biol Chem 275: 35814-35819.

Wollert T, Hurley JH. 2010. Molecular mechanism of multivesicular body biogenesis by ESCRT complexes. Nature 464: $864-869$.

Zarate YA, Hopkin RJ. 2008. Fabry's disease. Lancet 372: 1427-1435.

Zervas M, Dobrenis K, Walkley SU. 2001a. Neurons in Niemann-Pick disease type $\mathrm{C}$ accumulate gangliosides as well as unesterified cholesterol and undergo dendritic and axonal alterations. J Neuropathol Exp Neurol 60: 49-64.

Zervas M, Somers KL, Thrall MA, Walkley SU. 2001b. Critical role for glycosphingolipids in Niemann-Pick disease type C. Curr Biol 11: 1283-1287.

Zhang AS, Sheftel AD, Ponka P. 2005. Intracellular kinetics of iron in reticulocytes: evidence for endosome involvement in iron targeting to mitochondria. Blood 105: $368-375$.

Zhang R, Coleman T, Langmade SJ, Scherrer DE, Lane L, Lanier MH, Feng C, Sands MS, Schaffer JE, Semenkovich CF, et al. 2008. Niemann-Pick C1 protects against atherosclerosis in mice via regulation of macrophage intracellular cholesterol trafficking. J Clin Invest 118: 2281-2290.

Zschoche A, Fürst W, Schwarzmann G, Sanhoff K. 1994. Hydrolysis of lactosylceramide by human galactosylceramidase GM1- $\beta$-galactosidase in a detergent-free system its stimulation by sphingolipid activator proteins, sap-B sap-C. Activator proteins stimulate lactosylceramide hydrolysis. Eur J Biochem 222: 83-90. 


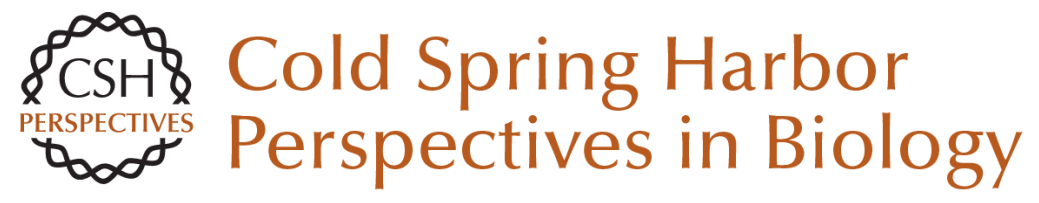

\section{Lysosomal Lipid Storage Diseases}

Heike Schulze and Konrad Sandhoff

Cold Spring Harb Perspect Biol 2011; doi: 10.1101/cshperspect.a004804 originally published online April 18,2011

\section{Subject Collection The Biology of Lipids}

Role of Lipids in Virus Replication Maier Lorizate and Hans-Georg Kräusslich

Model Answers to Lipid Membrane Questions Ole G. Mouritsen

\section{Glycosphingolipid Functions} Clifford A. Lingwood

Regulation of Cholesterol and Fatty Acid Synthesis

Jin Ye and Russell A. DeBose-Boyd

\section{Lipid-Mediated Endocytosis}

Helge Ewers and Ari Helenius

\section{Fluorescence Techniques to Study Lipid \\ Dynamics}

Erdinc Sezgin and Petra Schwille

Lysosomal Lipid Storage Diseases Heike Schulze and Konrad Sandhoff

\section{Distribution and Functions of Sterols and} Sphingolipids

J. Thomas Hannich, Kyohei Umebayashi and Howard Riezman
Membrane Organization and Lipid Rafts Kai Simons and Julio L. Sampaio

Shotgun Lipidomics on High Resolution Mass Spectrometers Dominik Schwudke, Kai Schuhmann, Ronny Herzog, et al.

Glycosphingolipid Functions Clifford A. Lingwood

Phosphoinositides in Cell Architecture Annette Shewan, Dennis J. Eastburn and Keith Mostov

Synthesis and Biosynthetic Trafficking of Membrane Lipids Tomas Blom, Pentti Somerharju and Elina Ikonen

Lipid Polymorphisms and Membrane Shape Vadim A. Frolov, Anna V. Shnyrova and Joshua Zimmerberg

Specificity of Intramembrane Protein-Lipid Interactions

Francesc-Xabier Contreras, Andreas Max Ernst, Felix Wieland, et al.

Dynamic Transbilayer Lipid Asymmetry Gerrit van Meer

For additional articles in this collection, see http://cshperspectives.cshlp.org/cgi/collection/

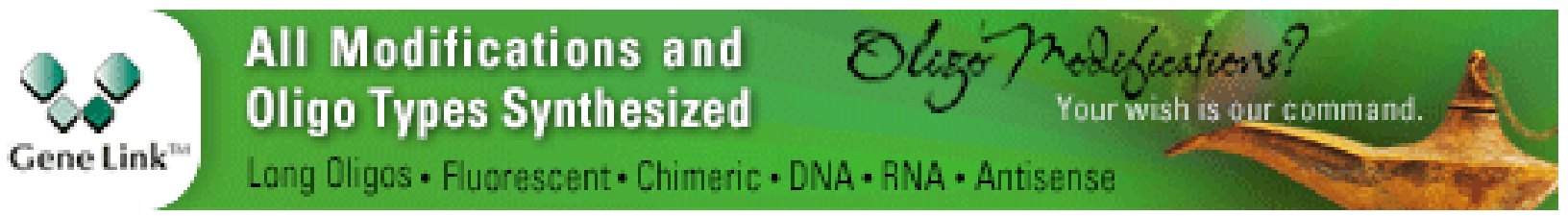

Copyright @ 2011 Cold Spring Harbor Laboratory Press; all rights reserved 